\title{
Recent developments in biotechnological improvement of Zoysia japonica Steud.
}

\author{
Hyeon-Jin Sun · In-Ja Song • Tae-Woong Bae $\cdot$ Hyo-Yeon Lee
}

Received: 1 November 2010 / Accepted: 18 November 2010

(C) Korean Society for Plant Biotechnology

\begin{abstract}
Zoysiagrass (Zoysia japonica Steud.), also called Korean or Japanese lawngrass, is the most popular warmseason turfgrass in Korea and is widely used for home lawns, parks, roadsides, golf courses and athletic fields. Its use is rapidly expanding in Korea and the other countries, due to its excellent characteristics which include tolerance to heat, drought and salinity. As the utilization area of this turfgrass increases, there is an increase in the demand for improved cultivars with disease and insect tolerance or with herbicidetolerance or with extended greening periods. Conventional breeding methods have been used to improve the traits described above with limited success. However, with the advances in biotechnology, genetic transformation can be utilized for turfgrass improvement. In this paper, we review recent progress in biotechnological improvement of zoysiagrass and discuss future molecular breeding of this species.
\end{abstract}

\section{서 론}

들잔디 (Zoysia japonica Steud.)는 한국을 포함한 극동아시 아와 대부분의 온대지역에 분포하는 난지형 잔디 중의 하나로 초장이 짧아서 예초에 강하고 열, 가뭄 및 염분에 대해 내성이 뛰어나며 일반적으로 병충해에 강한 잔디이

H.-J. Sun · I.-J. Song • T.-W. Bae • H.-Y. Lee

제주대학교 아열대원예산업연구소

(Subtropical Horticulture Research Institute, Jeju National

University, Jeju 690-756, Korea)

H.-Y. Lee $(\bowtie)$

제주대학교 생명공학부

(Faculty of Biotechnology, Jeju National University, Jeju

690-756, Korea)

e-mail: hyoyeon@jejunu.ac.kr
다. 그러나 몇몇 병충해에 대해서는 민감한 반응을 보이 며 기온이 $10^{\circ} \mathrm{C}$ 이하가 되면 휴면에 들어가 지상부가 고 사하여 녹색 유지기간이 한지형 잔디에 비해 짧고 음지 에서 잘 자라지 못하는 단점이 있다 (Inokuma et al. 1996; Lee et al. 2004). 잔디는 경관보호, 토양 및 수자원 보호, 신변보호 등 여러 가지 목적으로 활용되고 있으며, 도로, 하천, 비행장의 토양침식 방지에서부터 주택, 공원, 정원, 골프장, 스포츠 경기장 등으로 그 이용범위가 나날이 확 대되고 있다. 이로 인한 잔디의 급격한 수요 증가와 더불 어 잔디관련 사업규모가 크게 확대되고 있어 병해충 저 항성, 내한성, 제초제 저항성, 내음지성, 녹기 연장 등 다 양한 형질을 가진 잔디품종의 개발이 요구되고 있다. 지 금까지 들잔디의 품종육성은 전통적인 육종방법을 이용 하고 있으나 타 작물의 경우와 마찬가지로 고전육종기술 의 한계점들이 발견됨에 따라 최근에는 분자생물학적 방 법을 이용한 신품종 개발이 시도되고 있다 (Inokuma et al. 1998; Rim et al. 2001; Kim et al. 2004; Zhang et al. 2007).

분자생물학적 방법을 이용한 들잔디의 신품종 개발을 위해서는 먼저 조직배양과 형질전환체계가 확립되어야 한다. 들잔디의 조직배양에 관한 연구는 원형질체로부터 식물체 재분화 (Asano 1989; Inokuma et al. 1996), 미성숙 종자의 미숙배에서 유도한 캘러스로부터의 식물체 재분 화 (Park et al. 1994; Noh et al. 1995; Park and Ahn 1998), 성숙종자 유래 캘러스로부터의 식물체 재분화 (Al-Khayri et al. 1989; Rim et al. 2001; Bae et al. 2001; Lee et al. 2004) 등이 보고 된 바 있다. 그러나 원형질체를 이용한 조직배 양은 분리나 배양에 어려움이 있고 미성숙종자를 이용한 조직배양은 재료의 지속적인 확보가 어려워 그 활용이 크게 제한적이어서 최근의 들잔디 조직배양에 관한 연구 에는 주로 성숙종자 유래의 캘러스가 이용되고 있다 (Liu et al. 2009; Song et al. 2010). 들잔디의 형질전환에 관한 
연구는 원형질체를 polyethylene glycol (PEG)처리하여 $\beta$ -glucuronidase $(\mathrm{gus})$ 유전자를 도입한 것이 1998년에 최초로 보고되었으며 (Inokuma et al. 1998), 그 후 Agrobacterium 매개 형질전환에 관한 연구들이 보고되었다 (Toyama et al. 2003; Ge et al. 2006; Zhang et al. 2007). 본 논문에서는 생명공학 들잔디 개발을 위한 연구 현황 및 동향을 이해 하기 위하여, 현재까지 보고된 들잔디의 조직배양 및 형 질전환체계를 분석하고 개발된 형질전환 들잔디의 연구 현황 등에 대해 알아 보고자 한다.

\section{들잔디의 조직배양에 관한 연구 동향}

형질전환 기술을 이용한 신품종 들잔디의 개발에 있어서 가장 기본이 되는 것은 식물세포를 이용하여 고효율의 식물체 재분화가 가능한 조직배양체계를 확립하는 것이 며 이는 형질전환에 있어 매우 중요한 핵심기술이다. 서 론에서 언급한 바와 같이 들잔디의 조직배양체계 확립에 는 원형질체, 미성숙종자 및 성숙종자 등이 사용되었으 나, 최근에는 재료의 안정적인 확보가 가능하고 비교적 배양이 쉬운 성숙종자 유래의 캘러스가 주로 이용되고 있다. 잔디는 품종에 따라서 캘러스 유도, 증식 및 식물 체 재분화 능력에 큰 차이가 있으며, 특히 동일 품종에서 유도된 캘러스 간에도 형태학적인 특성과 재분화 능력이 다르다는 것이 알려져 있다 (Toyama et al. 2003; Liu et al. 2009; Song et al. 2010). 이러한 문제점을 해결하기 위해서 는 재분화가 잘 되는 형태의 캘러스를 선발하고 재분화 효율이 높은 계통을 확보 한 후, 균일한 형태의 캘러스 계통을 유지 및 대량 증식 할 수 있는 조건을 확립하는 것이 필요하다.

현재까지 보고된 들잔디의 조직배양체계 연구를 종합하 여 최적화된 조직배양 과정 및 배지조성을 Figure 1 (adopted from Song et al. 2010) 과 Table 1에 나타내었다. 그 내용을 간단히 살펴보면, 종피를 제거하고 표면 살균한 들잔디의 성숙종자를 캘러스 유도배지에 치상하여 캘러스를 유도 한다. 유도된 캘러스를 같은 배지에 계대배양하면서 1 3 개월간 배양하면 Figure 1c의 상부처럼 밝은 노란색의 캘 러스가 생성된다. 이런 형태의 캘러스만을 선발하여 캘러 스 증식 및 유지 배지에 치상하고 4 6 주 간격으로 계대
배양 후, 증식 능력이 좋고 재분화가 잘되는 형태 (Fig. 1d, yellow compact and very friable)의 배발생 캘러스 계통만 을 선발한다. 이렇게 선발된 각 계통의 캘러스는 재분화 시험을 수행하여 (Fig. 1e f) 최종적으로 재분화 능력이 좋 은 계통을 선발하고 유지·증식하면서 형질전환에 이용 하게 된다. 형질전환을 목적으로 한 들잔디의 조직배양 에서 가장 중요한 점은 재분화 능력이 좋은 캘러스를 선 발하고 그 캘러스를 균일한 형태로 유지·증식하는 것 이다. 성숙종자로부터 재분화능이 좋은 배발생 캘러스를 유도하는데는 MS기본배지에 2,4-D와 BA의 혼용처리가 가장 적합하고, 선발된 재분화능이 좋은 배발생 캘러스 를 균일한 형태로 유지 및 증식하는데는 2,4-D와 KI의 혼 용처리가 가장 적합한 것으로 나타났다. 선발된 배발생 캘러스의 재분화에는 sucrose 대신에 maltose를 사용하는
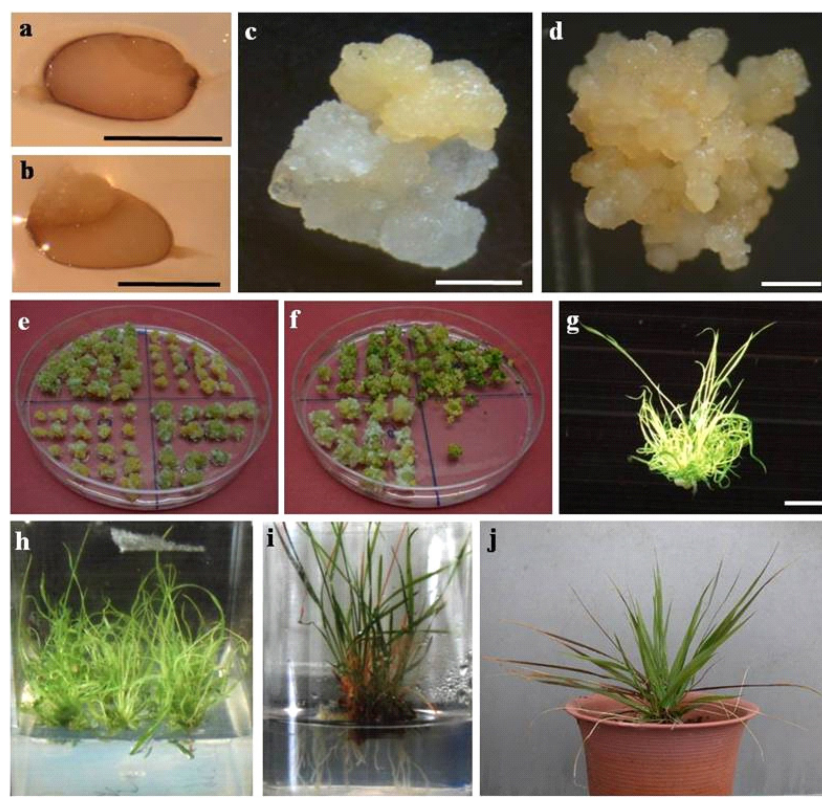

Fig. 1 Photographic representation of zoysia callus induction and plant regeneration (adopted from Song et al. 2010). (a) A mature seed of zoysiagrass used for this study. (b) Callusing response of a caryopsis after a week. (c) Microscopic view of a callus showing yellowish white and yellow colored parts. (d) A yellow colored calli selected for this study. (e) and (f) Regeneration potential of different types of calli. (g) A single callus clump showing multiple shoots. (h) Elongated multiple shoots. (i) Root induced shoot clusters. (j) Hardened plant in pot

Table 1 Composition of the media used for in vitro culture system of zoysiagrass

\begin{tabular}{|c|c|}
\hline Steps & Media \\
\hline Callus induction & $\begin{array}{l}\text { MS medium containing } 2 \mathrm{mg} / \mathrm{L} \text { 2,4-D, } 0.2 \mathrm{mg} / \mathrm{L} \mathrm{BA}, 4 \mathrm{mg} / \mathrm{L} \text { thiamine-HCl, } 100 \mathrm{mg} / \mathrm{L} \text { a-ketoglutaric acid, } \\
30 \mathrm{~g} / \mathrm{L} \text { sucrose, } 3 \mathrm{~g} / \mathrm{L} \text { Gelrite, } \mathrm{pH} 5.8\end{array}$ \\
\hline $\begin{array}{l}\text { Callus } \\
\text { growth/maintenance }\end{array}$ & MS medium containing $2 \mathrm{mg} / \mathrm{L}$ 2,4-D, $0.5 \mathrm{mg} / \mathrm{L} \mathrm{KI}, 30 \mathrm{~g} / \mathrm{L}$ sucrose, $3 \mathrm{~g} / \mathrm{L}$ Gelrite, $\mathrm{pH} 5.8$ \\
\hline Shoot induction & MS medium containing $1 \mathrm{mg} / \mathrm{L} \mathrm{BA}, 30 \mathrm{~g} / \mathrm{L}$ maltose, $3 \mathrm{~g} / \mathrm{L}$ Gelrite, $\mathrm{pH} 5.8$ \\
\hline Root induction & MS medium containing $30 \mathrm{~g} / \mathrm{L}$ sucrose, $3 \mathrm{~g} / \mathrm{L}$ Gelrite, $\mathrm{pH} 5.8$ \\
\hline
\end{tabular}



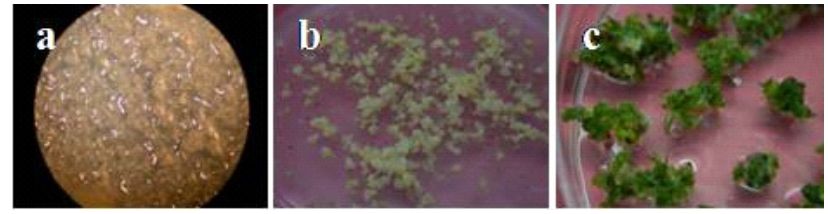

Fig. 2 Effect of suspension culture on callus growth and maintenance. (a) Embryogenic calli after 1 week incubation in suspension culture medium. (b) Embryogenic calli after 3 weeks incubation in suspension culture medium. (c) Plant regeneration of embryogenic calli obtained from suspension culture

것이 보다 효과적이었고, 호르몬 조합으로는 $\mathrm{BA}$ 단독처 리 (Toyama et al. 2003), NAA, KI, BA의 혼용처리 (Liu et al. 2009), 2-IP, $\mathrm{GA}_{3}$ (Song et al. 2010)의 혼용처리 등이 이 용되었으나 재분화 효율에는 큰 차이를 보이지 않았다. 다만, 2-IP와 $\mathrm{GA}_{3}$ 를 혼용처리 한 경우가 다른 처리구보다 multiple-shoots을 형성하는 경향이 있는 것으로 나타났다. 이상과 같이 들잔디의 조직배양체계가 확립되어 실제 형 질전환 들잔디 식물체 생산에 이용되고 있지만 식물체 재분화 능력이 있는 배발생 캘러스가 유도되는 효율이 매우 낮고 선발된 배발생 캘러스도 일정시간 (약 1 2년) 이 지나면 재분화 능력을 상실하게 되는 등의 문제점이 있어, 보다 안정적인 형질전환 식물을 생산하기 위해서 는 고효율의 배발생 캘러스 유도 및 유지·증식법의 개발 이 필요하다. 이에 본 연구진은 선발된 배발생 캘러스의 효율적인 유지 및 증식에 현탁배양법의 적합성을 검토하 였다. 그 결과 현탁배양에 의한 배발생 캘러스의 증식속 도는 기존의 고체 배양법보다 빨랐으며, 캘러스의 형태 도 고체배양한 것보다 균일함을 알 수 있었다. 또한, 현 탁배양에 의해 증식된 캘러스는 고체배양한 캘러스와 같 이 높은 재분화능을 유지함을 확인하였다 (Fig. 2). 현재 는 이 현탁배양법을 Agrobacterium 감염 직전의 캘러스 증식이나 전배양에 이용하고 있으며, 향후 재분화능을 유지하며 배양 할 수 있는 기간이 어느 정도인지 검토할 예정이다.

\section{들잔디의 형질전환방법에 관한 연구 동향}

들잔디의 안정적인 형질전환은 분리한 원형질체에 $\mathrm{PEG}$ 를 처리하여 유전자를 직접 도입시키는 방법으로 1998년에 처음 보고되었고 (Inokuma et al. 1998), 완전한 형질전환 식물체를 얻지는 못했지만 들잔디 미숙배에서 유도한 배 발생 캘러스에 electroporation을 이용하여 유전자를 도입 하는 방법이 보고되었다 (Park and Ahn 1998). 그러나 이 들 방법들은 재료를 얻기가 쉽지 않은 점, 도입 유전자 수가 많아 후대에 도입 유전자의 불활성화가 자주 발견 되는 점, 도입 유전자의 크기에 제한이 있는 점 등으로 인해 최근에는 많이 사용되고 있지 않다. 이에 비해
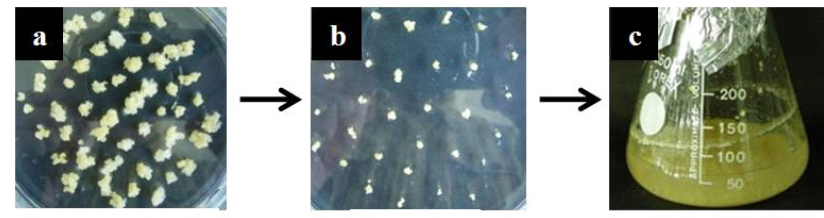

Embryogenic callus Pre culture
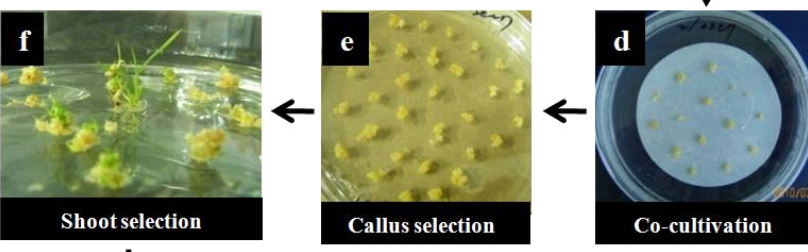

$\downarrow$

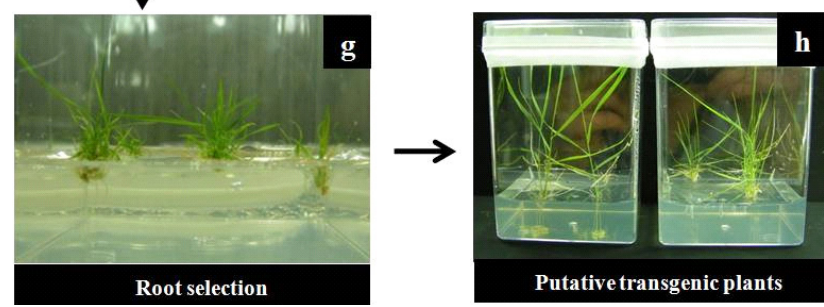

Fig. 3 Agrobacterium-mediated transformation procedures for zoysiagrass. Selected embryogenic calli were pre-cultured on pre-culture medium for 1 week prior to Agrobacterium infection. The calli were then immersed in Agrobacterium suspensions and incubated for 1 day with gentle shaking. The infected calli were co-cultivated in the dark at $25^{\circ} \mathrm{C}$ for 3 days. After the cocultivation, the calli were transferred onto callus selection medium and cultured under darkness for 3-6 weeks to select PPT-resistant calli. The selected calli were transferred to shoot selection medium and then induced shoots were transferred to shoot elongation medium. PPT-resistant shoots were transferred to root induction medium and then obtained putative transgenic zoysiagrass plants

Agrobacterium 을 이용한 형질전환은 경제적이고, 도입 유 전자의 수가 적으며, 비교적 분자량이 큰 유전자도 안정 적으로 도입이 가능하여 효율적인 형질전환 방법으로 알 려져 있다. 들잔디의 Agrobacterium을 매개로 한 형질전환 은 성숙종자 유래의 배발생 캘러스를 이용한 연구가 2003 년 (Toyama et al.)과 2007년 (Zhang et al.)에 보고되었고 2006년에는 성숙종자 유래의 배발생 캘러스가 아닌 stolon 을 이용한 형질전환 방법도 보고되었다 (Ge et al. 2006). 이 중에서 stolon을 이용한 형질전환은 방법이 간단하고 단시간에 형질전환 식물을 얻을 수 있는 장점이 있다고 생각되어 우리 연구소에서도 시도해 보았으나 안정적인 재료의 확보가 어렵고, 무엇보다 식물재료의 오염 제거 가 쉽지 않은 문제점이 있어 실제로 형질전환에 적용하 기에는 효율적이지 못한 측면이 있다고 판단되었다.

현재까지 보고된 들잔디의 배발생 캘러스를 이용한 Agrobacterium 매개 형질전환 방법과 현재 우리 연구소에 서 이용하고 있는 형질전환 방법을 종합한 형질전환 과 정과 배지조성은 Figure 3 과 Table 2에 나타낸 바와 같다. 
Table 2 Composition of the media used for zoysiagrass transformation

\begin{tabular}{|c|c|c|}
\hline Steps & Period & Media \\
\hline Pre-culture I & 7 days & MS medium containing $2 \mathrm{mg} / \mathrm{L}$ 2,4-D, $0.5 \mathrm{mg} / \mathrm{L} \mathrm{KI}, 30 \mathrm{~g} / \mathrm{L}$ sucrose, $3 \mathrm{~g} / \mathrm{L}$ Gelrite, $\mathrm{pH} 5.8$ \\
\hline Pre-culture II & 7 days & $\begin{array}{l}\text { MS medium containing } 2 \mathrm{mg} / \mathrm{L} 2,4-\mathrm{D}, 0.5 \mathrm{mg} / \mathrm{L} \mathrm{KI}, 30 \mathrm{~g} / \mathrm{L} \text { sucrose, } \mathrm{pH} 5.8 \text { (add } 50 \mathrm{mg} / \mathrm{L} \\
\text { AS } 1 \text { day before infection) }\end{array}$ \\
\hline Infection & 24 hours & $\begin{array}{l}\text { MS medium containing } 2 \mathrm{mg} / \mathrm{L} \text { 2,4-D, } 0.01 \mathrm{mg} / \mathrm{L} \mathrm{BA}, 30 \mathrm{~g} / \mathrm{L} \text { sucrose, } 50 \mathrm{mg} / \mathrm{L} \mathrm{AS}, \mathrm{pH} \\
5.8\end{array}$ \\
\hline Co-cultivation & 3 days & $\begin{array}{l}\text { MS medium containing } 2 \mathrm{mg} / \mathrm{L} \text { 2,4-D, } 0.01 \mathrm{mg} / \mathrm{L} \mathrm{BA}, 30 \mathrm{~g} / \mathrm{L} \text { sucrose, } 50 \mathrm{mg} / \mathrm{L} \mathrm{AS}, 3 \mathrm{~g} / \mathrm{L} \\
\text { Gelrite, } \mathrm{pH} 5.8\end{array}$ \\
\hline Callus selection I & $1-2$ weeks & $\begin{array}{l}\text { MS medium containing } 2 \mathrm{mg} / \mathrm{L} 2,4-\mathrm{D}, 0.01 \mathrm{mg} / \mathrm{L} \text { BA, } 30 \mathrm{~g} / \mathrm{L} \text { sucrose, } 3 \mathrm{~g} / \mathrm{L} \text { Gelrite, } 1 \\
\mathrm{mg} / \mathrm{L} \text { PPT, } 250 \mathrm{mg} / \mathrm{L} \text { Cefotaxime, } \mathrm{pH} 5.8\end{array}$ \\
\hline Callus selection II & 2-4 weeks & $\begin{array}{l}\text { MS medium containing } 2 \mathrm{mg} / \mathrm{L} 2,4-\mathrm{D}, 0.5 \mathrm{mg} / \mathrm{L} \mathrm{KI}, 30 \mathrm{~g} / \mathrm{L} \text { sucrose, } 3 \mathrm{~g} / \mathrm{L} \text { Gelrite, } 5 \mathrm{mg} / \mathrm{L} \\
\text { PPT, } 250 \mathrm{mg} / \mathrm{L} \text { Cefotaxime, } \mathrm{pH} 5.8\end{array}$ \\
\hline Shoot induction & 4 weeks & $\begin{array}{l}\text { MS medium containing } 1 \mathrm{mg} / \mathrm{L} \mathrm{BA}, 30 \mathrm{~g} / \mathrm{L} \text { maltose, } 3 \mathrm{~g} / \mathrm{L} \text { Gelrite, } 1 \mathrm{mg} / \mathrm{L} \mathrm{PPT}, 250 \mathrm{mg} / \mathrm{L} \\
\text { Cefotaxime, pH } 5.8\end{array}$ \\
\hline Shoot elongation & 4 weeks & $\begin{array}{l}\text { MS medium containing } 1 \mathrm{mg} / \mathrm{L} \mathrm{BA}, 1 \mathrm{mg} / \mathrm{L} \mathrm{GA}_{3}, 30 \mathrm{~g} / \mathrm{L} \text { maltose, } 3 \mathrm{~g} / \mathrm{L} \text { Gelrite, } 1 \mathrm{mg} / \mathrm{L} \\
\text { PPT, } 250 \mathrm{mg} / \mathrm{L} \text { Cefotaxime, } \mathrm{pH} 5.8\end{array}$ \\
\hline Root induction & 2-4 weeks & $\begin{array}{l}\text { MS medium containing } 30 \mathrm{~g} / \mathrm{L} \text { sucrose, } 3 \mathrm{~g} / \mathrm{L} \text { Gelrite, } 5 \mathrm{mg} / \mathrm{L} \text { PPT, } 250 \mathrm{mg} / \mathrm{L} \text { Cefotaxime, } \\
\text { pH } 5.8\end{array}$ \\
\hline
\end{tabular}

간단히 살펴보면, 선발된 재분화 능력이 좋은 배발생 캘 러스를 Agrobacterium 접종 약 1주일 전에 전배양 배지에 서 배양하고, Agrobacterium 을 재현탁한 액체감염배지에서 약 24 시간 동안 현탁 배양하여 감염 한 후 약 3 일간 공동 배양한다. 이 후 bialaphos 또는 phosphinothricin (PPT)을 포 함하는 캘러스 선발배지에서 약 3 6주간 배양하며 살아 있는 캘러스를 선발한 후 재분화 배지에 치상하고 재분 화를 유도한다. 유도된 재분화 식물체는 뿌리를 유도하 고 충분히 증식시킨 후 목적유전자의 도입 여부를 확인 한다. 매 실험마다 선발 단계별 소요 기간에 상당한 차이 가 있지만, 들잔디의 형질전환체 생산에는 대략 6 9개월 이 걸리는 것으로 보여진다. 이런 과정을 통한 들잔디의 형질전환 효율은 약 $1 \%$ 전후이고, 형질전환에 사용된 배 발생 캘러스의 계통에 따라 그 효율 및 재현성에 큰 차이 를 보이고 있다. 배발생 캘러스를 이용한 들잔디의 형질 전환에서는 재분화 효율이 높고 Agrobacterium에 감염능 이 좋은 배발생 캘러스를 선발하는 것이 가장 중요한 것 으로 보이며, Agrobacterium 접종 단계에서의 처리방법 역 시 형질전환 효율에 큰 영향을 미치는 것으로 여겨진다. Agrobacterium 접종 전단계로 캘러스를 Agrobacterium 접 종 3 7일 전에 전배양배지에 처리하거나 접종 하루 전에 $50 \mathrm{mg} / \mathrm{L}$ 의 acetosyringone(AS)을 첨가한 액체감염배지에 처리하는 방법과 Agrobacterium 배양 시에 acetosyringone 을 첨가하는 등 여러 조건이 검토되었고 이와 같은 처리 들은 형질전환 효율을 높이는데 효과가 있는 것으로 생 각되고 있다. Toyama 등(2003)은 칼슘과 2,4-D를 포함하 지 않고 $\mathrm{pH}$ 를 5.2로 조정한 감염배지 및 공동배양 배지를 사용하여 Agrobacterium 을 접종하면 형질전환 효율이 증

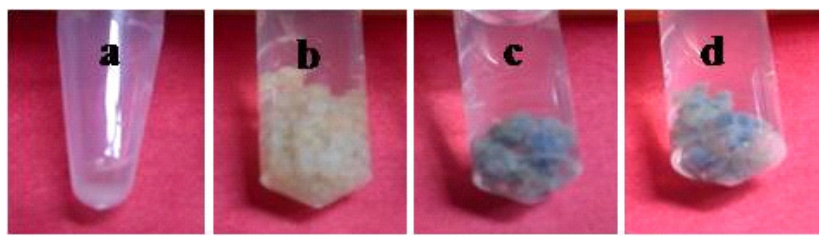

Fig. 4 Transient GUS expression after infection of Agrobacterium on embryogenic calli. (a) Agrobacterium cells. (b) Embryogenic calli infected with Agrobacterium for $30 \mathrm{~min}$. (c) Sonicationtreated embryogenic calli infected with Agrobacterium for 30 min. (d) Embryogenic calli infected with Agrobacterium for 24 h After Agrobacterium infection, the embryogenic calli cocultured for 3 days. And then GUS expression was observed

대됨을 보고 하였고, Kim 등 (2004)은 particle bombardment 를 이용하여 캘러스에 상처를 유발 시킨 후 Agrobacterium 을 감염시키면 무처리구에 비하여 3 배 이상 높은 형질전 환 효율을 보인다는 연구 결과를 보고한 바 있다. 본 연 구진은 Agrobacterium 감염 직전의 캘러스를 초음파 처리 하여 형질전환 효율에 미치는 영향을 검토 하였는데, 초 음파 처리구는 무처리구에 비해 월등히 높은 형질전환 효율을 나타내었다 (Fig. $4 \mathrm{~b} \sim \mathrm{c}$ ). 그러나 캘러스에 상처를 유발하는 전처리는 감염효율을 증대시키는 효과는 있었 지만 박테리아의 과잉증식 등에 의한 영향으로 재분화 효율이 크게 감소하는 문제점이 있었다. 이 외에도 감염 시의 Agrobacterium 농도, 감염시간, 공동배양 기간 등이 형질전환 효율에 미치는 영향이 검토 되었다 (Toyama et al. 2003; Kim et al. 2004; Zhang et al. 2007). 이들 결과를 살펴보면, 감염시의 Agrobacterium 의 농도가 높을수록 그 리고 감염시간 및 공동배양 기간이 길어질수록 캘러스로 
의 유전자 도입 효율은 증가하였으나 박테리아에 의한 오염이 심각하여 공동배양 후의 캘러스를 멸균수 등으로 세정하는 과정을 필요로 했다. 그러나 한번 박테리아에 오염된 캘러스는 세정 등의 과정을 거치더라도 또다시 박테리아의 오염이 생길 가능성이 높고, 재분화 효율 역 시 매우 낮아지게 되므로 성공적인 들잔디 형질전환을 위해서는 감염효율을 최대한 높이면서 동시에 박테리아 의 과잉 증식이 되지 않는 감염조건의 확립이 필요하였 다. 이에 본 연구진은 전배양배지 (Pre-culture I 또는 Preculture II 배지)에서 전배양한 캘러스를 Agrobacterium 의 농도를 $\mathrm{OD}_{600 \mathrm{~nm}}=0.1$ 로 조정한 감염배지에서 24 시간 동 안 감염하고 (현탁배양; $25^{\circ} \mathrm{C}, 110 \mathrm{rpm}$ ), 3 일간 공동배양 함으로서 박테리아의 오염을 최소화 하면서도 형질전환 효율은 초음파 처리구 (Fig. 4c) 에 크게 뒤지지 않는 감염 방법을 고안하였다 (Fig. 4d). 또한 위와 같은 연구 결과들 을 토대로 수립된 형질전환체계를 이용하여 제초제 저항 성, 음지회피성 조절, 환경 스트레스 내성 관련 유전자 등을 도입한 형질전환 들잔디를 제조하여 그 특성을 분 석하고 있다. 그러나 형질전환 들잔디 개발 관련 학술지 발표는 현재까지도 10 개가 되지 않을 정도로 미미한 결 과를 보이고 있는데, 이는 재현성 있고 안정적인 형질전 환이 매우 어려움을 단적으로 보여주는 것이라 생각된 다. 따라서 다양한 특성을 가진 실용적 가치가 있는 형질 전환 들잔디의 개발을 위해서는 보다 효율적이고 안정적 인 조직배양 및 형질전환체계를 확립하기 위한 연구가 지속적으로 수행되어야 할 것으로 판단된다.

\section{형질전환 들잔디 개발에 대한 연구 동향}

잔디는 지피식물로 경관 미화, 토양침식 방지, 공원 및 골프장 등의 조경용으로 이용되어 왔으나, 오늘날 잔디 의 사용은 보다 다양해져서 아파트, 학교, 병원, 스포츠 경기장 등에도 점차 재배면적이 증가하고 있어 다양한 용도의 품종 개발이 요구되고 있다. 특히 병해충 저항성, 내한성, 제초제 저항성, 녹기 연장 등의 형질을 가진 품 종개발이 필요한데, 이 중 병해충 저항성과 제초제 저항 성은 전통적인 육종 방법으로는 만들어지기 매우 힘든 형질들로 생각되고 있다. 따라서 이러한 형질을 도입시 키기 위하여 Agrobacterium 을 이용한 식물 형질전환 기술 이 이용되었고 최근 제초제 저항성 유전자 (Toyama et al. 2003)와 해충 저항성 유전자 (Zhang et al. 2007)가 도입된 형질전환 들잔디가 개발되었다. 현재까지 특정형질을 부 여하기 위해 개발된 형질전환 들잔디는 이 두 가지 사례 밖에 보고되지 않아 한지형 잔디인 벤트그라스 (Agrostis stolonifera L.)의 형질전환 잔디 개발 (Hwang and Kim 2009) 과 비교하면 그 결과는 미미한 편이다. 이는 잔디 초종의 중요성이나 경제성에 따른 것이 아니라 형질전환의 효율
차이에서 기인한 것으로 보인다. Bacillus thuringiensis 유 래의 해충 저항성 유전자 $(\operatorname{cryIA}(b))$ 를 도입한 형질전환 들잔디에 관한 연구는 목적유전자의 도입과 발현을 확인 한 결과만이 보고 되었고 (Zhang et al. 2007) 목표형질을 분석한 연구결과는 아직 보고 되어 있지 않다.

잔디밭에서의 잡초는 잔디와 경합하여 잔디의 퇴화를 초래하기 때문에 잡초방제는 중요한 관리 작업 중의 하 나로 막대한 노동력과 비용이 투입되어야 한다. 이런 잡 초를 방제하기 위해 대부분 선택성 제초제를 사용하였지 만 모든 잡초 종류에 대한 효과적인 방제 방법은 아직 없 는 실정이다. 따라서 이들 잡초의 효과적인 방제와 과다 한 농약의 사용 등을 줄이기 위해 비선택성 제초제에 저 항성을 가지는 제초제 저항성 들잔디가 개발되었다. 제 초제 저항성 유전자 (bar)가 도입된 형질전환 들잔디는 비선택성 제초제인 바스타에 저항성을 가짐이 확인 되었 고 (Fig. 5, adopted from Toyama et al. 2003), GMO 격리포 장에서 수년간 재배한 지금도 그 목표형질이 유지 되고 있다. 이러한 제초제 저항성 들잔디는 목표형질의 발현 이 안정적이고 잔디의 신품종으로서 충분한 실용적 가치 가 있다고 판단되어 현재 상업재배를 위한 농업용 유전 자 변형 생물체의 환경위해성심사를 진행 중에 있다. 형 질전환에 의해 개발된 유전자 변형 식물의 상업화를 위 해서는 반드시 환경위해성평가를 수행하여 유전자 변형 식물이 생태계에 유해한 영향을 미치지 않음을 증명해야 한다. 제초제 저항성 들잔디 (Zoysia japonica Steud. Jeju green21)는 환경위해성 평가 항목 중에서 매우 중요한 위 치를 차지하는 화분의 비산에 따른 유전자의 이동성 (Fig. 6, adopted from Bae et al. 2008)을 포함하여 비 표적 생물체로의 수평적 유전자 이동 (Horizontal Gene Transfer) 가능성 (Fig. 7 8, adopted from Bae et al. 2007), 인체에 대 한 알러지 반응성 (Table 3, adopted from Bae et al. 2008) 등 각종 환경 위해성 평가를 수행하였다. 제초제 저항성 들잔디로부터 야생형 들잔디로의 유전자 이동 가능성은 여러 형태의 시험 모형을 이용하여 평가 되었다. 이 중

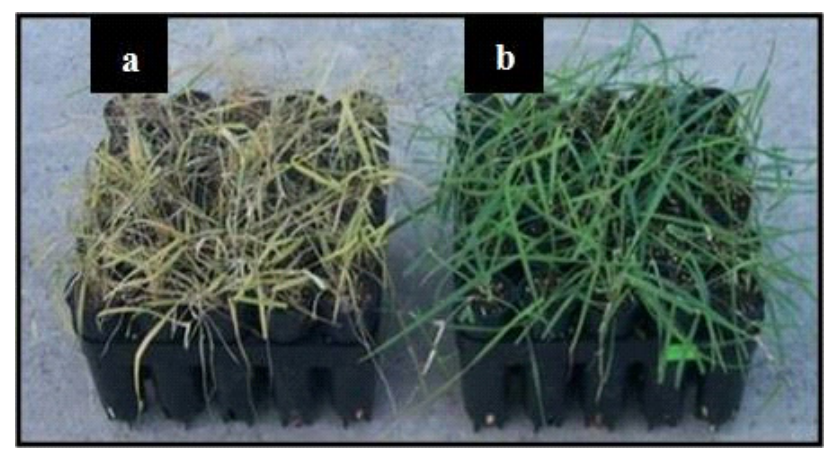

Fig. 5 Herbicide applications to non-transformed plants (a) and transgenic plants (b) (adopted from Toyama et al. 2003) 


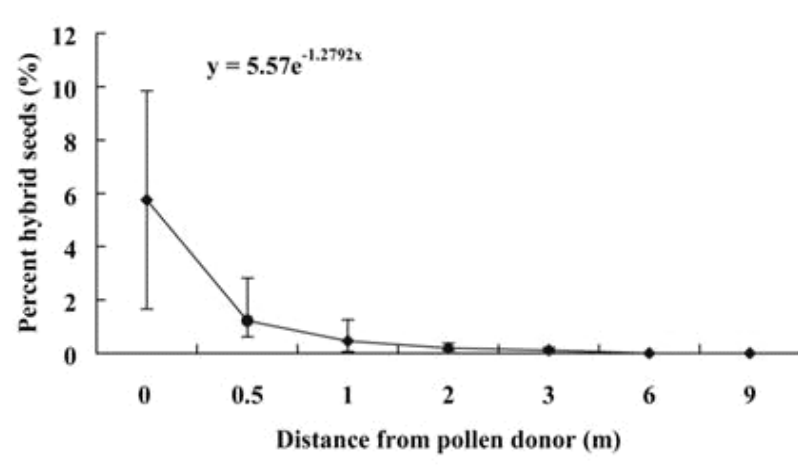

Fig. 6 Distance dependence for gene flow from the genetically modified to wild-type zoysiagrass within 9-m radius in field (adopted from Bae et al. 2008)

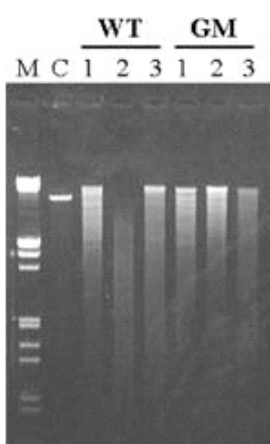

(a)

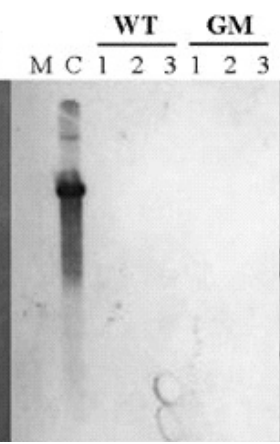

(b)

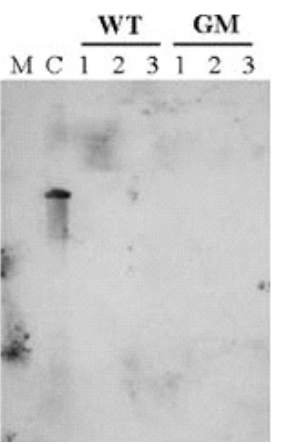

(c)
Fig. 7 Southern hybridization analyses of microbial genomic DNAs digested with HindIII and probed with DIG-labeled bar and $h p t$ gene fragments (adopted from Bae et al. 2007). (a) Ethidium bromide-stained agarose gel. (b) Southern blot hybridized with bar probe. (c) Southern blot hybridized with hpt probe. WT, samples from wild type zoysiagrass field; GM, samples from GM zoysiagrass field; C, positive vector control; 1, DNA from soil microbes; 2, DNA from rhizosphere microbes; 3 , DNA from microbes in faecal pellets from locusts

제초제 저항성 들잔디로부터 반경 $9 \mathrm{~m}$ 이내의 야생형 들 잔디와의 교배 가능성 검정 모형에서의 시험 결과, $0.5 \mathrm{~m}$ 거리에서 약 $1.2 \%$ 의 교배율이 관찰되었고 $3 \mathrm{~m}$ 이상의 거 리에서는 자연 교배된 식물체는 관찰되지 않았다 (Fig. 6). 따라서 비선택성 제초제 저항성 들잔디의 유전자 이동 가능성은 $3 \mathrm{~m}$ 이상의 거리에서는 매우 낮을 것으로 생각 되고 있다. 토양에는 유전자 변형 식물을 포함한 다양한 식물에서 방출된 DNA가 지속적으로 남아 있을 수 있기 때문에 유전자 변형 작물에서 비 표적생물체로의 수평적 유전자전달은 유전자 변형 식물의 환경위해성 평가에서 중요한 요소 중 하나이다. Bae 등 (2007)은 GMO격리포장 에 식재된 제초제 저항성 들잔디의 근권세균을 포함한 토양미생물 및 풀무치의 장내 미생물로의 bar 유전자 및 $h p t$ 유전자의 전달 여부를 Southern blot (Fig. 7) 및 genomicPCR (Fig. 8)을 이용하여 조사하였다. 그 결과 비선택성

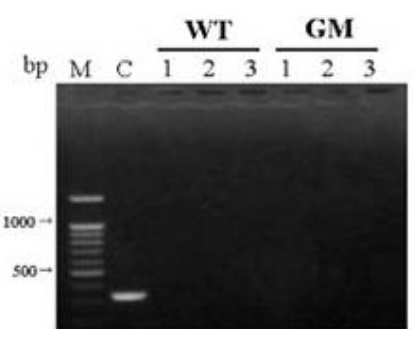

(a)

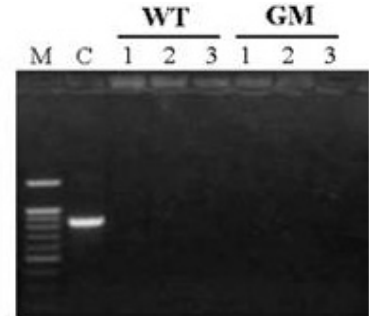

(b)
Fig. 8 PCR analysis for detecting bar gene (a) and hpt gene (b) in microbes isolated from wild-type and GM field (adopted from Bae et al. 2007) C, positive vector control; 1, DNA from soil microbes; 2, DNA from rhizosphere microbes; 3, DNA from microbes in faecal pellets from locusts

Table 3 Results from the skin prick tests for common and Zoysiagrass allergens (adopted from Bae et al. 2008)

\begin{tabular}{lcc}
\hline \multicolumn{1}{c}{ Allergen } & $\begin{array}{c}\text { No. of } \\
\text { Patients }\end{array}$ & $\begin{array}{c}\text { Positive } \\
\text { reaction }(\%)\end{array}$ \\
\hline $\begin{array}{l}\text { Positive control } \\
(1 \mathrm{mg} / \mathrm{mL} \text { histamine })\end{array}$ & 127 & 100 \\
\hline Negative control & 0 & 0 \\
\hline Dermatophagoides farinae & 72 & 56.7 \\
\hline Dermatophagoides pteronyssinu & 60 & 47.2 \\
\hline American cockroach & 36 & 28.3 \\
\hline German cockroach & 39 & 30.7 \\
\hline Cat and dog hair & 18 & 14.2 \\
\hline Horse and cattle hair & 4 & 3.2 \\
\hline Flag & 3 & 2.4 \\
\hline Broadleaf tree & 2 & 1.6 \\
\hline Acicular tree & 6 & 4.7 \\
\hline Japanese cedar & 5 & 3.9 \\
\hline American cedar & 6 & 4.7 \\
\hline House dust-fungi & 8 & 6.3 \\
\hline Outdoor fungi & 6 & 4.7 \\
\hline Flowers & 1 & 9.4 \\
\hline Weeds & 14 & 11.0 \\
\hline Crops & 6 & 7.9 \\
\hline GM Zoysiagrass & & 4.7 \\
\hline WT Zoysiagrass & 4.7 \\
\hline
\end{tabular}

제초제 저항성 들잔디로부터 토양 미생물이나 비표적생 물인 풀무치의 장내 세균으로의 수평적 유전자전달은 확 인되지 않았다. 또한 제조제 저항성 들잔디의 인체 알러 지 반응성이 검사되었는데, 이 검사에는 20 개의 공통항 원을 포함하여 야생형과 제초제 저항성 들잔디의 화분단 백질이 이용되었다. 검사 결과, 야생형과 제초제 저항성 들잔디의 알러지 감작률은 동일한 수치를 나타내었고 (Table 3, adopted from Bae et al. 2008) 이는 들잔디의 알러 
지 유발성이 유전자 도입에 의한 영향을 받지 않았음을 시사한다. 이들 결과에서 제초제 저항성 들잔디는 환경 에 대한 위해성이 매우 낮을 것으로 생각되고 있다. 이러 한 제초제 저항성 들잔디가 현재 진행중인 상업재배를 위한 농업용 유전자 변형 생물체의 환경위해성심사를 통 과하여 상업화에 성공한다면 분자육종을 통한 신품종 작 물개발의 좋은 모델이 되어 국내 작물육종 산업의 발전 에 크게 기여할 수 있을 것으로 생각된다.

현재까지 개발된 형질전환 들잔디는 제초제 저항성과 해충 저항성의 두 종류에 불과하지만, 앞으로 환경 스트 레스 저항성, 노화지연 등 고부가가치 형질이 도입된 형 질전환 들잔디 식물체들이 개발되어, 지속적으로 증가하 고 있는 잔디 품종에 대한 수요에 부응 할 수 있을 것으 로 기대하고 있다.

\section{결 론}

잔디 산업은 지난 30 여년 동안 지속적으로 성장해 왔으 며 최근에는 생활수준의 향상에 따라 잔디의 이용 범위 가 확대되어 다양한 용도로 사용되고 있다. 따라서 사용 목적에 적합한 다양한 형질의 잔디 품종의 개발이 요구 되고 있다. 전통육종을 이용한 품종 개량은 시간과 비용 이 많이 들 뿐만 아니라 개량 가능한 형질에도 한계가 있 기 때문에 최근에는 식물형질전환 기술을 이용한 품종 개발 연구가 많이 수행되고 있다. 우리나라에서 가장 많 이 이용되고 있는 들잔디에 대한 조직배양 및 형질전환 체계가 개발되었고 이를 이용하여 해충 저항성 잔디 및 제초제 저항성 잔디 등이 개발되었다. 이 외에도 우리 연 구소에서는 환경 스트레스 내성 관련 형질전환 잔디를 제조하여 그 특성을 분석 중에 있고 노화지연 유전자, 내 음지성 유전자 등을 도입한 형질전환 들잔디 식물체를 생산하고 있다. 지금까지 유전자 변형 농산물의 안전성 에 대한 논란이 제기되고 있음에도 불구하고 새로운 형 질을 가진 유전자 변형 작물이 개발되고 있고 그 재배면 적도 점차 확대되고 있는 추세이다. 전세계에서 현재까 지 24 개 작물, 155 계통이 환경위해성평가를 통과하여 인 가되었고, 2009년 현재 유전자 변형 작물의 재배면적은 약 1 억 3 천만ha에 이르며 이는 유전자 변형 작물의 상업 재배가 시작된 1996년의 약 80배에 달하는 수치이다 (ISAAAbrief 41, 2009, http://www.isaaa.org). 이런 상황 하에서 아직 까지 우리나라에는 환경위해성 평가를 거쳐 인가된 유전 자 변형 작물은 없는 실정이며, 분자육종 분야에서 국제 적 경쟁력을 가지기 위해서는 실용적 가치가 높은 다양 한 유용 형질을 도입한 유전자 변형 작물의 개발이 시급 하게 수행 되어야 할 것으로 보여진다.

\section{사 사}

본 논문은 정부(교육과학기술부)의 재원으로 한국연구재 단의 대학중점연구소 지원사업으로 수행된 연구임(20100029630).

\section{인용문헌}

Al-Khayri JM, Huang FH, Thompson LF, King JW (1989) Plant regeneration of zoysiagrass from embryo-derived callus. Crop Sci 29:1324-1325

Asano Y (1989) Somatic embryogenesis and protoplast culture in Japanese lawngrass (Zoysia japonica). Plant Cell Rep 8: $141-143$

Bae CH, Toyama K, Lee SC, Lim YP, Kim HI, Song PS, Lee HY (2001) Efficient plant regeneration using mature seed-derived callus in zoysiagrass (Zoysia japonica Steud.). Kor J Plant Tissue Culture 28:61-67

Bae TW, Lee HY, Ryu KH, Lee TH, Lim PO, Yoon PY, Park SY, Riu KZ, Song PS, Lee YE (2007) Evaluation of horizontal gene transfer from genetically modified zoysiagrass to the indigenous microorganisms in isolated GMO field. J Plant Biotechnol 34:75-80

Bae TW, Vanjildorj E, Song SY, Nishiguchi S, Yang SS, Song IJ, Chandrasekhar T, Kang TW, Kim JI, Koh YJ, Park SY, Lee J, Lee YE, Ryu KH, Riu KZ, Song PS, Lee HY (2008) Environment risk assessment of genetically engineered herbicidetolerant Zoysia japonica. J Environ Qual 37: 207-218

Ge Y, Norton T, Wang ZY (2006) Transgenic zoysiagrass (Zoysia japonica) plants obtained by Agrobacterium-mediated transforamation. Plant Cell Rep 25:792-798

Hwang OJ, Kim JI (2009) Recent advances in the development of biotech bentgrass. J Plant Biotechnol 36:327-335

Inokuma C, Sugiura K, Cho C, Okawara R, Kaneko S (1996) Plant regeneration from protoplasts of Japanese lawngrass. Plant Cell Rep 15:737-741

Inokuma C, Sugiura K, Imaizumi N, Cho C (1998) Transgenic Japanese lawngrass (Zoysia japonica Steud.) plants regenerated from protoplasts. Plant Cell Rep 17:334-338

Kim JB, Kim KD, Park DS (2004) Establishment of a transformation protocol combination particle bombardment with Agrobacterium tumefaciens in different zoysiagrass cultivars. Kor Turfgrass Sci 18:141-148

Lee SH, Kim BS, Won SH, Jo J, Kim KY, Park GJ, Sung BR, Lee HS, Lee BH (2004) Factors affecting callus induction and plant regeneration from mature seed of zoysiagrass (Zoysia japonica Steud.). J Kor Grassl Sci 24:29-36

Liu L, Fan X, Zhang Z, Yan M, Bao M (2009) Long-term cultured callus and the effect factor of high-frequency plantlet regeneration and somatic embryogenesis maintenance in Zoysia japonica. In Vitro Cell Dev Biol-Plant 45:673-680

Noh HY, Choi JS, Ahn BJ (1995) Plant regeneration through somatic embryogenesis in zoysiagrass (Zoysia spp.). J Kor Soc 
Hort Sci 36:582-587

Park GH, Choi JS, Yun CH, Ahn BJ (1994) DNA delivery into embryogenic cells of zoysiagrass (Zoysia japonica Steud.) and rice (Oryza sativa L.) by electroporation. Kor J Plant Tissue Culture 21:309-314

Park GH and Ahn BJ (1998) Electroporation conditions for DNA transfer into somatic embryogenic cells of Zoysia japonica. Kor J Plant Tissue Culture 25:13-19

Rim YW, Kim KY, Choi GJ, Lim YC, Sung BY (2001) Callus induction and plant regeneration from seeds of Zoysia japonica Steud. J Kor Grassl Sci 21:49-52
Song IJ, Ganesan M, Kang EJ, Sun HJ, Bae TW, Lim PO, Song PS, Lee HY (2010) A simple and reproducible regeneration protocol for Zoysia japonica based on callus cultures. Hort Environ Biotechnol 51:222-225

Toyama K, Bae CH, Kang JG, Lim JG, Adachi T, Riu KZ, Song PS, Lee HY (2003) Production of Herbicide-tolerant zoysiagrass by Agrobacterium-mediated transformation. Mol Cells 16: 19-27

Zhang L, Wu D, Zhang L, Yang C (2007) Agrobacterium-mediated transformation of Japanese lawngrass (Zoysia japonica Steud.) containing a synthetic cryIA (b) gene from Bacillus thuringiensis. Plant Breeding 126:428-432 